\title{
Assessment of organic pollutants of water samples in River Getsi and River Gwagwarwa in Kano State Nigeria
}

\author{
Y. Mohammed ${ }^{1}$, A. Ekevwe ${ }^{2}$ \\ ${ }^{1}$ Department of Chemistry, Nigeria Defence Academy, Kaduna, Kaduna State \\ ${ }^{2}$ Department of Chemistry, Federal College of Education (Technical) Bichi, Kano State
}

Email address:

sawaba83@gmail.com (Y. Mohammed), upambrose@yahoo.com (A. Ekevwe)

\section{To cite this article:}

Y. Mohammed, A. Ekevwe. Assessment of Organic Pollutants of Water Samples in River Getsi and River Gwagwarwa in Kano State Nigeria. Journal of Water Resources and Ocean Science. Vol. 3, No. 1, 2014, pp. 1-4. doi: 10.11648/j.wros.20140301.11

\begin{abstract}
Water samples of River Gwagwarwa and River Jakara were analyzed for organic pollutants. The organic parameters were determined using the standard methods of America Public Health Agency (APHA) and was extracted and analyzed using Gas chromatography-mass spectrometer (GC-MS). Thirteen different organic compounds were detected at different percentage values at the two sampling stations. The compounds fall within five classes of organic compounds, which include carboxylic acid, acid chloride, ester, aldehyde and acid anhydride. The distribution pattern of the organic pollutant at the two sampling stations depict the pattern; River Gwagwarwa > River Getsi .The study shows that organochloride was the predominant organic pollutant present in the samples
\end{abstract}

Keywords: Gas Chromatography, Mass Spectrometer, Carboxylic Acid, Acid Chloride, Ester, Aldehyde, Organochloride, Organic Pollutant

\section{Introduction}

Water is the most common liquid on our planet, vital to life form. The total water on earth is enormous, estimated to $1.5 \times 1018$ metric tons; this quantity is 300 times larger than the mass of the entire atmosphere [1]. Unfortunately, most of these are not accessible because they appear in icecaps, oceans, in underground aquifer (ground water-bearing beds) and some are even in the air as moisture .Only a small fraction of water is on earth surface and directly accessible to man as rivers, streams and springs [2].

Water can sometimes be said to be pure but it can never entirely $100 \%$ pure. It inevitably carries traces of other substances - various organic compounds, particles, gases, minerals and ions which impart to its physical, chemical and bacteriological characteristics [3].

In cities of Nigeria, with particular reference to Kano state, a major industrial and commercial centre with a population of over 7,000,000 people according to the national census figure of 2006.The various component of the natural environment are often adversely affected by these human activities resulting in the devastation of components of the environment such as air, land and water [4].

The quality of water is continuously changing as a result of the reaction of water with contact media affected by anthropogenic influences, such as domestic or municipal waste [5]. The behavior of organic compounds is dependent upon their molecular structures, size and shape and the presence of functional groups that which are important determinants of toxicity, (Adeola, 2004). There are many different types of organic pollutants, examples are:Hydrocarbons, Polu Aromatic Hydrocarbon's, Polycyclic Biphenyl's, Detergents,plastic, persistent organic pollutant,pesticide among others.

Many organic compounds, to a varying degree, resist photolytic, biological and chemical degradation. These are referred to as persistent organic pollutants (POPs). POPS are often halogenated and characterized by low water solubility and high lipid solubility, leading to their bioaccumulation in fatty tissues. They are also semivolatile, enabling them to move long distances in the atmosphere before deposition occurs, (Ritter et al., 2007).

Although many different forms of POPs may exist, both natural and anthropogenic, many of these compounds have been or continue to be used in large quantities and, due to their environmental persistence, have the ability to bioaccumulate and biomagnify. Some of these compounds such as polycyclic biphenyls (PCBs), may persist in the environment for periods of years and many bioconcentrate by factors of up to 70,000 fold, (Ritter et al., 2007). 
Pesticides (synthetic organic chemicals) are widely used in fruit and vegetable production because of their susceptibility to insects and diseases attack. Consequently, food safety is a major public concern worldwide as residues of pesticides could affect the ultimate consumers especially when these commodities are freshly consumed. Given the potential risk of pesticides and heavy metals for public health, the use of pesticides in fruit and vegetable production is subjected to constant monitoring.

An assessment report carried out by Ritter et al., (2007) on several organic pollutants concluded that a number of the organic substances assessed in the report have been implicated in a broad range of adverse human health environmental effects including impaired reproduction and endocrine dysfunction, immunosuppression and cancer. In many cases, the substances are considered as possible human carcinogens by the International Agency for Research on Cancer consumed [11,12,13\&14]..

\section{Study Site}

River Gwagwarwa originate from Gwagwarwa quarter under Nassarawa local government area of Kano State. Gwagwarwa is a highly populated town in Kano. This is because of its semi-industrial nature and proximity to Sabon Gari (a densely residential and commercial settlement) in Kano. Therefore the River cut across domestic, industrial and agricultural areas which makes it to carry along pollutant due to the activities of the areas it pass through.

River Getsi originate from Bompai industrial areas, Bompai in Nassarawa local government area of Kano State.
Pollution loads in River Getsi are through industrial operations in Bompai and proximate localities.

\section{Material and Method}

Water samples were collected at various points along River Getsi and River Gwagwarwa in the morning and evening on each sampling day. $100 \mathrm{~cm} 3$ of water sample was collected at each designated point which is 20 metres to the next point[8,9]. 10 samples were collected in each sampling session which are composited to a total of 1 litre. The samples were labeled and taken to the laboratory for further analysis[8,9,10]. This procedure was repeated throughout the sampling. Appropriate quantities of the composite samples were measured and treated according to the standard methods of American Public Health Agency (APHA).

\section{Procedure}

$50 \mathrm{~cm}^{3}$ of each composite water sample was measured and added into a cleaned $250 \mathrm{~cm}^{3}$ separatory funnel. $50 \mathrm{~cm}^{3}$ each of diethyl ether and trichloromethane were measured and added into the separatory funnel.. The resultant mixtures was vigorously shaken and gas released intermittently by controlling the lid. The mixture was allowed to stand on a retort stand for 5 minutes and the organic layer was collected in a cleaned glass sample bottle, labeled and kept for further GC-MS analysis [7].This process was repeated for all the composite samples.

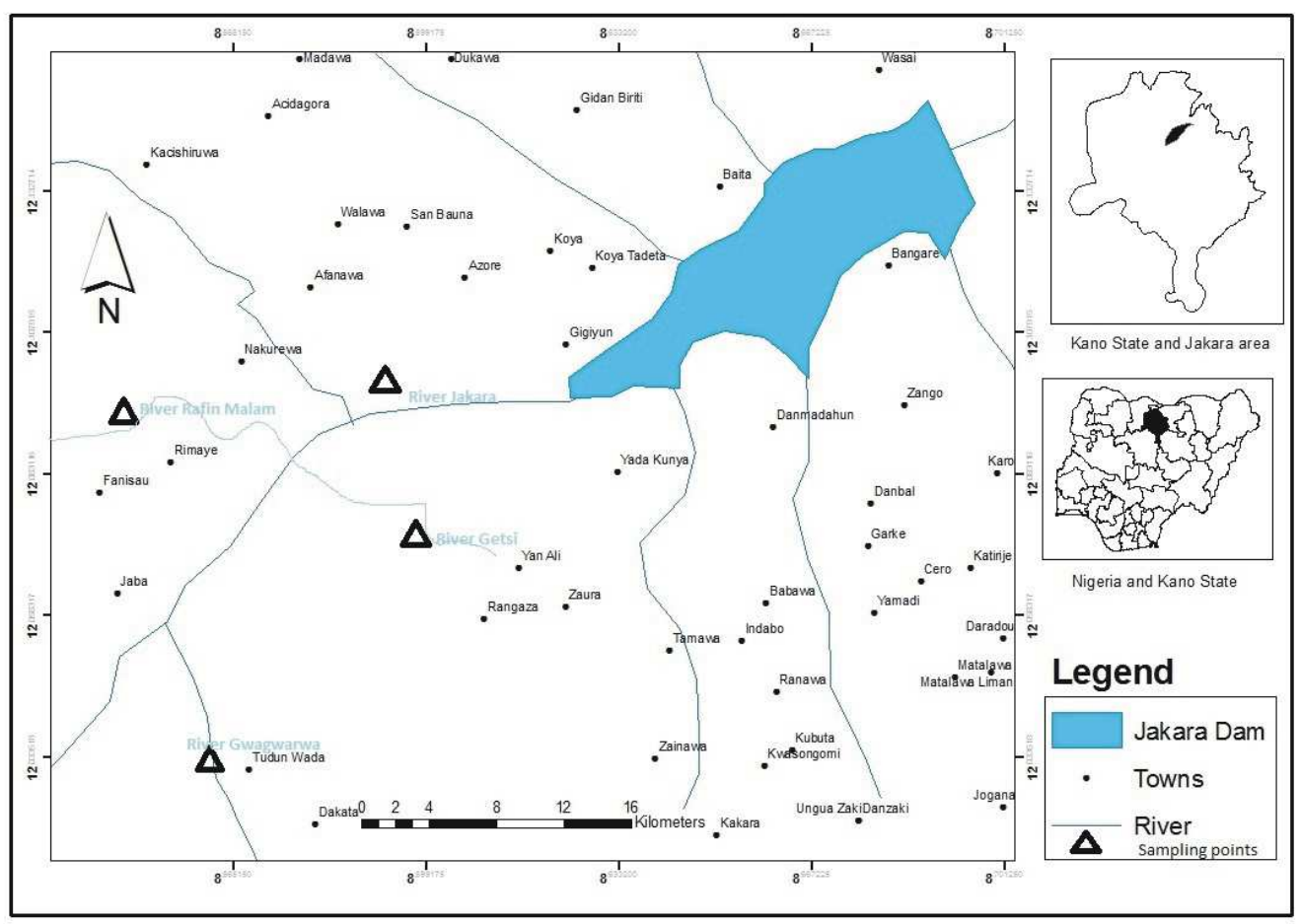

Figure 1. Map Showing River Getsi and River Gwagwarwa with other Rivers across River Jakara 
Table 1. Average Percentage (\%) Value of Organic Compound Detected at River Getsi Samples

\begin{tabular}{clc}
\hline S/No & Compound Detected & \% Value \\
\hline 1 & Dodecanoic Acid & $1.98 \pm 0.47$ \\
2 & Tetradecanoic Acid & $2.39 \pm 0.48$ \\
3 & Palmitic Acid & $9.59 \pm 2.86$ \\
4 & Methyl Octadecanoate & $7.03 \pm 1.65$ \\
5 & Oleic Acid & $34.07 \pm 5.88$ \\
6 & Docosanoic Anhydride & $9.75 \pm 1.37$ \\
7 & Octadecanoic acid 1,2,3 Propanetriyl Ester & $31.93 \pm 8.13$ \\
8 & 9- hexadecanoic Acid & $11.58 \pm 2.79$ \\
9 & Octadecadienoyl Chloride & $55.19 \pm 0.0$ \\
10 & Hexadecanoic Acid 1- \{\{\{2-Aminoethylhodroxy Phosphinyl\} Oxy\} Methyl $\}-1,2$ Ethenediyl Ester & $9.32 \pm 0.0$ \\
\hline
\end{tabular}

Table 2. Average Percentage (\%) Value of Organic Compound Detected at River Gwagwarwa

\begin{tabular}{clc}
\hline S/No & Compound Detected & \% Value \\
\hline 1 & Dodeconoic Acid & $1.93 \pm 0.51$ \\
2 & Tetradecanoic Acid & $2.39 \pm 0.40$ \\
3 & Palmitic Acid & $9.17 \pm 2.47$ \\
4 & Methyl Octadecanoate & $7.39 \pm 1.39$ \\
5 & Oleic Acid & $29.46 \pm 6.42$ \\
6 & Docosanoic Anhydride & $12.03 \pm 1.44$ \\
7 & Octadecanoic acid 1,2,3 Propanetriyl Ester & $41.05 \pm 8.66$ \\
8 & 9-Hexadecanoic Acid & $24.81 \pm 0.0$ \\
9 & 1,3 Octadecanal & $12.94 \pm 0.0$ \\
10 & Octadecadienoyl Chloride & $66.66 \pm 0.0$ \\
\hline
\end{tabular}

\section{Result and Discussion}

The $\%$ values of the various organic compounds detected in the composite water sample collected from River Getsi are presented in table 1.0. Ten different organic compounds were detected at different $\%$ value. The compounds falls within four classes of organic compounds viz, carboxylic acid, acid chlorides, acid anhydride and esters. The distribution of the compounds depicts a pattern; carboxylic acid $>$ esters $>$ acid chlorides $=$ acid anhydride. Highest percentage value of 55.19 was recorded for octadecadienoyl chloride and the least $\%$ value of 2.31 was recorded both for dodecanoic acid and tetradecanoic acid.

Exposures to Dodecanoic acid and tetradecanoic acid can cause mild irritation of the upper respiratory tract and mucous membrane at higher concentration which is in accordance with U.S Department of Health and Human Behaviour. While exposures to Octadecadienoyl chloride are very toxic and dangerous, it causes severe burns and eye damage. Human exposure present at level greater or equal to $0.1 \%$ is identified as probable, possible or confirmed human carcinogen by International Agency for Research on Cancer (IARC).

These classes of organic compound arises in the wastewater due to discharges of complex chemicals and solvent used in commercial, agricultural and industrial operations[15\&16].

The $\%$ values of the various organic compounds detected in the composite water sample collected from River Gwagwarwa are presented in table 2.0. Ten different organic compounds were detected at different $\%$ value. The compounds falls within five classes of organic compounds viz, carboxylic acid, esters, acid anhydride, acid chlorides and aldehyde. The distribution of the compounds depicts a pattern; carboxylic acid $>$ esters $>$ acid chlorides $=$ aldehyde $=$ acid anhydride. Highest percentage value of 66.66 was recorded for octadecadienoyl chloride and the least $\%$ value of 1.76 was recorded for dodecanoic acid.

Exposures to Dodecanoic acid can cause mild irritation of the upper respiratory tract and mucous membrane at higher concentration which is in accordance with U.S Department of Health and Human Behaviour. While exposures to Octadecadienoyl chloride are very toxic and dangerous, it causes severe burns and eye damage. Human exposure present at level greater or equal to $0.1 \%$ is identified as probable, possible or confirmed human carcinogen by International Agency for Research on Cancer (IARC).

These classes of organic compound arise in the wastewater due to the discharges of complex chemicals and solvent used in commercial, agricultural and industrial operations[15\&16]. 


\section{References}

[1] S.O Ajah and O. Osidayo (1981). Pollution studies on Nigerian Rivers: Water quality of some Nigeria Rivers, Environ Pollution, serv, B, 2: 87-95

[2] O. Dimitrovska, B. Markoski, B.A Toshevska, I. Mileveka and S. Gorin (2012). Surface water pollution of major rivers in the Republic Of Macedonia, Procedia Environ Sci, 14, $32-40$

[3] .J Driver (1997); The geochemistry of natural waters: Surface and groundwater environments. $3^{\text {rd }}$ ed. Upper Saddle Rivers, NJ: Prentice Hall.

[4] A.L. Vittoli, C. Trivisano, C. Gessa, M. Gherardi, A. Simoni and G. Vienello (2010). Quality of Municipal wastewater compared to surface waters of the river and artificial canal network in different areas of the eastern Po Valley (Italy). Water qual Expo Health, 2 (1), 1-13).

[5] O. Osidayo, P.D Adegbeuro and M.G Adewole (2011): The impact of industries on surface water quality of River Ona and River Alero in Oluyole industrial estate, Ibadan, Nigeria. African Journal of Biochemistry, 10 (4), 696-702.

[6] M.O Said (2008) Chemical analysis of water samples in Kano state. Ph.d Thesis, Bayero University, Kano. Nigeria. PP 125-128.

[7] G. Wyasu and Kure, O.A (2012): Determination of organic pollutants in hospital waste water and food samples within Ahmadu Bello University Teaching hospital (ABUTH) Shika, Zaira- Nigeria. Available online at www.pelagiaresearchlibrary.com

[8] APHA(1998); Standard Methods for the Examination of
Water and Wastewater. America Public Health Association, $18^{\text {th }}$ ed, Academic Press, Washington, D.C Pp. 200-240.

[9] APHA(2005); Standard Methods for the Examination of Water and Wastewater. America Public Health Association, $19^{\text {th }}$ ed, Academic Press, Washington, D.C Pp. 80-95.

[10] Burton, F.L Tchobanoglous, G. And Stensel, H.D (2003); Waste Water Engineering (Context Treatment, disposal and Reuse) Metcalf \& Eddy Inc ( $4^{\text {th }}$ Ed) McGraw-Hill book company New York).

[11] Damià, B. (2005) ; Emerging Organic Pollutants in Waste Waters and Sludge. Springer, Berlin.

[12] David T Allen and David R. Shunnart, (2000); Green Engineering - Environmentally Conscious Design of Chemical Processes, pp $201-207$ prentice Hall

[13] Eldon D. Enger and Bradltey F. Smith (2010); Environmental Science (Study of Interrelationship) 12 Edition, McGraw-Hill Publishers, New York Pp 335 - 425.

[14] EPA (2007); United State Environmental Protection Agency, National Water Quality Inventory" Report to Congress for the 2002 Reporting Cycle-Profile Washington DC.

[15] European Commission (2006); Environmental fact sheet: reach a new chemical policy for EU commission, Luxembourg.

[16] Eichelberger, J W Belymer., T.D and Budde, W.L (1988); Determination of Organic compounds in Drinking Water by Liquid and Solid Extraction and Circularly column Gas Chromatography/Mass Spectrometry (Method 525 2, Revised 2.0) National Exposure Research Laboratory Office of Research and Development USEPA Cincinnati, Ohio 45268. 